\title{
Egy figyelmen kívül hagyott lehetőség
}

- avagy az átmeneti védelemről szóló irányelv és a migrációs és menekültügyi válsághelyzetek és vis maior események kezelésérôl szóló rendelet alkalmazhatósága a lakóhelyüket természeti okokból elhagyni kényszerült személyekre vonatkozóan

\author{
A Missed Opportunity \\ - The Applicability of the Temporary Protection Directive \\ and the Regulation on Addressing Situations of Crisis \\ and Force Majeure in the Field of Migration and Asylum \\ to Environmentally Displaced Persons
}

Az Egyesült Nemzetek Szervezetének menekültügyi intézménye (UNHCR) szerint 2017-ben összesen 30,6 millió ember kényszerült újonnan elhagyni lakóhelyét világszerte. Ezeknek az embereknek több mint fele - a közvélekedéssel ellentétben - nem fegyveres konfliktus miatt kényszerült elhagyni lakóhelyét, hanem természeti katasztrófa miatt. Ebből kifolyólag az ENSZ felfogása szerint az államok kötelesek humanitárius védelmet nyújtani minden embernek. A nemzetállamok álláspontja szerint azonban a lakóhelyüket tömeges mértékben elhagyni kényszerülök veszélyt

Nemzeti Közszolgálati Egyetem Államtudományi és Nemzetközi Tanulmányok Kar Nemzetközi Jogi Tanszék, tanársegéd. E-mail: horvath.valeria.eszter@uni-nke.hu 
jelentenek a befogadó ország gazdasági, társadalmi és politikai biztonságára. Gyakran azonban ezeket a biztonsági kockázatokat képtelenek egyedül kezelni. Mindeközben az EU számos, különböző olyan jogsegélyt nyújt a tagállamoknak, mint például a 2001-es Átmeneti Védelemröl szóló Irányelv. Mivel az Európai Unió nem tudta a rendelkezésre álló eszközökkel megfelelöen kezelni a 2015-ös migrációs válságot, az Európai Bizottság 2020-ban bejelentette az Uj Migrációs és Menekültügyi Csomagot, amelyben többek között az Irányelv is reformra itéltetett, és egy új, a migrációs és menekültügyi válsághelyzetek és vis maior események kezeléséről szóló rendelet váltaná fel azt. Jelen tanulmány célja, hogy górcső alá vegye az Irányelv és a Rendelet célját és alkalmazásának lehetöségeit a lakóhelyüket természeti katasztrófa miatt elhagyni kényszerülő személyekre vonatkozóan.

Kulcsszavak: új migráció és menekültügyi csomag, migráció, menekültügy, átmeneti védelem, azonnali védelem, válságkezelés, környezeti migráció

In 2017, a total of 30.6 million people were forced to leave their homes worldwide, according to the UNHCR. More than half of these people - contrary to the popular belief-were not forced to leave their homes due to armed conflict, but due to a natural disaster. For this reason, the United Nations believes that states have a duty to provide humanitarian protection to all people. However, nation states take the view that those forced to leave their homes en masse pose a threat to the economic, social and political security of the host country. Often, however, they are unable to manage these security risks alone. In the meantime, the European Union provides a number of different legal aids to Member States, such as the 2001 Temporary Protection Directive. Since the EU was not able to adequately address the 2015 migration crisis with the available means, the European Commission announced in 2020 a New Migration and Asylum Package, which announced, among other things, the reform of the Directive, which would be replaced by a regulation on addressing situations of crisis and force majeure in the field of migration and asylum. The aim of the present study is to examine the purpose of the Directive and the Regulation and the possibilities of their application to persons forced to leave their place of residence due to a natural disaster.

Keywords: new pact on migration and asylum, migration, asylum, temporary protection, immediate protection, crisis management, environmentally displaced, climate displacement

\section{Bevezetés}

Az ENSZ Menekültügyi Főbiztossága (UNHCR) szerint 2017-ben összesen 30,6 millió ember kényszerült újonnan elhagyni lakóhelyét világszerte. Ezeknek az embereknek már több mint fele - a közvélekedéssel ellentétben - nem fegyveres konfliktus 
következtében kényszerült elhagyni lakóhelyét, hanem természeti katasztrófa miatt. ${ }^{1}$ Egyébként már az 1980-as évektől napvilágot láttak olyan becslések, amelyek a „klímamenekültek”, illetve a „környezeti migránsok” számát 25 milliótól kezdve egészen 1 milliárdra teszik. ${ }^{2} \mathrm{~A}$ becslések szórása és pontatlansága pedig a jelenség definiálatlanságából ered. Az elmúlt évtizedekben a médiában, a tudományos kutatásokban és a nemzetközi szervezetek gyakorlatában is felváltva jelentek meg a „klímamigráns”, „lakóhelyüket elhagyni kényszerülő” (internally displaced persons), „menekülő”, illetve „menedékkérő” megnevezések. Idén a Nemzetközi Migrációs Szervezet (IOM) ${ }^{3}$ az éves rendes Migrációs Világjelentésében már egy gyűjtőfogalmat, az „emberi mobilitást” (human mobility) említi, mintegy elkerülve a politikai felhangú „migráció”-t, illetve a nemzetközi jog által szúken értelmezendő értelmű menekültjogi fogalmakat. Ez a tágabb fogalmi kategória ugyanis magában foglalja a közvetlen és közvetett kényszerhelyzetre reagálókat és az önkéntesnek vélt, de legalábbis előre megtervezett módon elvándorlókat is.

Az éghajlatváltozásnak közvetlen és közvetett következményei is vannak. Az Internal Displacement Monitoring Center (IDMC) szerint az éghajlatváltozás közvetlen következményei lehetnek hirtelen, illetve gyors lefolyásúak, vagy lehetnek hosszútávon jelentkező, lassú lefolyású hatásai is. ${ }^{4}$ Az éghajlatváltozás hirtelen jelentkező, illetve gyors lefolyású következménye például az erdőtűz, a szélvihar és az áradás. Ezek következtében az IDMC adatai szerint 2019-ben Kínában 3,762 millió, az USA-ban 1,247 millió, a Fülöp-szigeteken 3,802 millió, Indiában 2,675 millió embernek kellett elhagynia a lakóhelyét. ${ }^{5}$ Ezek bekövetkezésekor a helyiek arra kényszerülnek, hogy elhagyják lakóhelyüket, és vagy egyénileg keresnek „menedéket”, vagy a - helyi, állami vagy nemzetközi - katasztrófavédelmi hatóságok evakuálják őket előre meghatározott katasztrófavédelmi protokollok szerint.

Ugyanakkor kifejezetten az éghajlatváltozásnak számos fokozatosan bekövetkező, illetve viszonylag lassú lefolyású hatása van. Ilyen maga a globális felmelegedés, a szárazság, az elsivatagosodás, a kiszámíthatatlan és megnövekedett csapadék, a jégolvadás, a tengerszint-emelkedés, a vízhiány, az óceánok elsavasodása. Ezek inkább közvetve eredményeznek elvándorlást az által, hogy például a változó éghajlati környezet már nem teszi lehetővé a megszokott élelmezést vagy jövedelemszerzést. Az Élelmezésügyi és Mezőgazdasági Világszervezet (FAO) felmérései szerint a szárazságból és elsivatagosodásból fakadóan a talaj elveszti termékenységét, a felborult hidrológiai körforgás miatt megnövekedett csapadék kiszámíthatatlanná teszi a mezőgazdaságot, a vizek elsavasodása, illetve felmelegedése pedig ellehetetleníti a halászatot. ${ }^{6}$ Ennek eredményeként veszélybe kerül az élelmiszer-ellátás, a gazdaság egésze, és a mezőgazdászként dolgozóknak két lehetőségük marad: vagy beköltöznek a városba, vagy mezőgazdasági

Internal Displacement Monitoring Center: Global Report on Internal Displacement (2018); International Organisation for Migration: Migration, Environment and Climate Change: Assessing the Evidence. Geneva, Switzerland, 2009. 9.

2 IOM: Environmental Migration Portal: https://environmentalmigration.iom.int/environmental-migration

3 International Organisation for Migration: World Migration Report 2020. Geneva, Switzerland, 2019. 9. fejezet.

Internal Displacement Monitoring Center: No matter of choice: displacement in a changing climate (2018). 2. Internal Displacement Monitoring Center: Global Report on Internal Displacement (2019).

Food and Agriculture Organization: Drought: www.fao.org/land-water/water/drought/en/

Európai Tükör 2021/2. 
munkát keresnek ott, ahol még van mezőgazdaság, még akkor is, ha ez egy másik országban van.

A fentiek alátámasztásául számos jelenlegi migrációs trendre hivatkozhatunk. A FAO 2018-as jelentése szerint az Egyesült Államokba „tóduló” bevándorlók túlnyomó többsége is Közép-Amerika (Honduras, Guatemala, El Salvador) mezőgazdasági területeiről származik. ${ }^{7}$ A médiában is látványosan megjelenített afrikai migráció valóban megduplázódott az elmúlt 15 évben. ${ }^{8} 1950$ óta Afrikában a termőföldek 65\%-a vesztette el termékenységét, miközben 2030-ra az élelmiszerigény 50\%-kal, a víz iránti igény 30\%-kal, az energia iráni igény $45 \%$-kal fog megnőni. ${ }^{9}$ Mindazonáltal az afrikai kivándorlók 80\%-a Afrikán belül keres és talál új otthonra. ${ }^{10}$ Ázsia és a Csendes-óceáni-szigetek lakosai a globális népesség majdnem 60\%-át teszik ki, globális viszonylatban pedig a nemzetközi migránsok 30\%-át, miközben 2000 és 2009 között a természeti katasztrófák halálos áldozatainak 85\%-a volt ázsiai. ${ }^{11} \mathrm{Az}$ Ázsiai Fejlesztési Bank szerint 2050-re Indiában 37,2 millió, Bangladeshben 27 millió, Kínában 22 millió, Indonéziában 20 millió és egyedül a Fülöp-szigeteken 13 millió embert fenyeget a tengerszint-emelkedés. ${ }^{12}$ Végül az alkalmazkodás tekintetében fontos megjegyezni, hogy a nemzetközi munkaerőigényhez alkalmazkodó körkörös migráció, például a mezőgazdaságra jellemző idénymunka céljából történő bevándorlás jellemző az afrikai kontinensen (a szubszaharai és a Száhel-öv alatti területekről), az amerikai kontinensen (Közép-Amerikából, Dél-Amerikából) és Délkelet-Ázsiában is (India, Bangladesh, Thaiföld). A FAO szerint 2050-re a Globális Délen (Global South) 143 millió ember keresi majd megélhetését a kontinens más országaiban. ${ }^{13}$

Az ENSZ álláspontja az éghajlatváltozással összefüggő népmozgás, illetve a tágabb értelemben vett környezeti migrációval kapcsolatban az, hogy az államok kötelesek humanitárius védelmet nyújtani minden embernek. 2016. szeptember 19-én 193 állam jelentette ki az ENSZ Közgyűlésen, hogy szükség van a nemzetközi mobilitás átfogó, globális szabályozására, így a Migránsokról és Menekültekről szóló New York-i Nyilatkozat második mellékletében egy újabb kormányközi egyeztetési folyamatot irányoztak elő. A konzultációs folyamat 2018. december 10-én zárult le, a Global Compact for Safe, Orderly and Regular Migration címú dokumentummal, amelyet az ENSZ Közgyúlés 2018. december 19-én jóvá is hagyott. ${ }^{14}$ A 23 alapcél közül kettőben nevesítették kifejezetten a környezetromlást, illetve az éghajlatváltozást. A második alapcél szerint minimalizálni kell az olyan strukturális tényezőket és negatív ösztönzőket, amelyek arra késztetik az embereket, hogy elhagyják származási országukat. Az ötödik alapcél szerint pedig szükséges, hogy a szabályos migráció (regular migration) módozatai elérhetők és kellően

Food and Agriculture Organization: Atlas migración en los países del norte de Centroamérica: www. fao.org/americas/noticias/ver/en/c/1174658/

African Union: Report on Labour Migration Statistics in Africa (2017).

Awil Mohamoud - Alpha Kaloga - Sönke Kreft: Climate change, development, and migration: an African Diaspora Perspective. German Watch - African Diaspora Policy Center, 2014.

Africa Center for Strategic Studies: African Migration Trends to Watch in 2021 (2020).

Asian Development Bank: Addressing Climate Change and Migration in Asia and the Pacific (2012).

Asian Development Bank (2012): i. m.

Food and Agriculture Organization: The Linkages between Migration, Agriculture, Food Security, and Rural Development (2018).

14

Lásd: www.iom.int/sites/default/files/our_work/ODG/GCM/NY_Declaration.pdf 
rugalmasak legyenek azok számára, akiket az éghajlatváltozás lassú lefolyású hatásai késztetnek arra, hogy lakóhelyüket elhagyják.

Mind a politikai közbeszédben, mind a nemzetbiztonságot hangsúlyozó tudományos vitákban előkerül az a felvetés, hogy a lakóhelyüket elhagyni kényszerülő személyek tömeges beáramlása veszélyt jelent a fogadó ország gazdasági, társadalmi és politikai biztonságára. Ezt az állami veszélyérzetet fokozza az is, hogy gyakran ezeket a biztonsági kockázatokat képtelenek az egyes országok egyedül kezelni. Pontosan ezért és a regionális stabilitás megőrzéséért regionális szinten az Európai Unió számos, olyan (jog)segélyt nyújt a tagállamainak, amelyek az információmegosztás és az ügyteherelosztás által kívánják minimalizálni a vélt vagy valós biztonsági kockázatokat. Ilyen például az Átmeneti Védelemről szóló Irányelv ${ }^{15}$ (vagy Irányelv), amelynek célja pontosan a tömeges méreteket öltő migráció kezelésének elősegítése a tagállami szuverenitás érintése nélkül, de az Európai Unió koordinációjával. Az Irányelvben meghatározott segélymechanizmust sosem aktiválták, és az új menekültügyi reformból kifolyólag már nem is fogják. Az Irányelvet mostantól felváltja a migrációs és menekültügyi válsághelyzetek és vis maior események kezeléséről szóló rendelet (Válságkezelési Rendelet). ${ }^{16}$

A jelen tanulmány alapját az Európai Bizottság 2016-os jelentése ${ }^{17}$ képezi, amelynek célja és eredménye az Irányelv alkalmazási körének, lehetőségeinek és tapasztalatainak összefoglalása és értékelése volt. Ezt a tapasztalati összefoglalót fogom összevetni az új Migrációs és Menekültügyi Csomag válságkezelési tervével. Kutatásom során szeretném feltárni, hogy az Irányelv alkalmazható lett volna-e - az Irányelv tényállási elemeit vizsgálva - a lakóhelyüket környezeti okokból elhagyni kényszerülők tekintetében, valamint, hogy az új Válságkezelő Rendelet vonatkozhat-e a jövőben a lakóhelyüket természeti katasztrófa miatt elhagyni kényszerülő személyekre.

\section{Az Átmeneti Védelemrôl szóló Irányelv}

Ugyan az Irányelv a közösségi szabályozásban úttörő volt, maga az átmeneti védelem koncepciója nem volt új vagy idegen a tagállamok számára. Az Irányelvben meghatározott átmeneti védelem mellett számos formája volt már az Irányelv előtt is az ideiglenes, vagyis időben korlátozott jogi státuszoknak, mivel az 1951-es Menekültügyi Egyezmény rendszere a gyakorlatban lassúnak és rugalmatlannak bizonyult.

Az átmeneti intézkedések bevezetésére főleg az 1990-es években volt szükség, mivel ebben az évtizedben két európai háború is lezajlott. A Boszniából és Koszovóból érkezőknek többek között Ausztria, Belgium, Franciaország, Dánia, Írország, Lengyelország, Németország, Spanyolország és Svédország adott kedvezményes feltételekkel ideiglenes,

\footnotetext{
15 A Tanács 2001/55/EK Irányelve (2001. július 20.) a lakóhelyüket elhagyni kényszerült személyek tömeges beáramlása esetén nyújtandó átmeneti védelem minimumkövetelményeiről, valamint a tagállamok e személyek befogadása és a befogadás következményeinek viselése tekintetében tett erőfeszítései közötti egyensúly előmozdítására irányuló intézkedésről (angolul röviden: Temporary Protection Directive).

16 Európai Bizottság: Javaslat Az Európai Parlament és a Tanács Rendelete a migrációs és menekültügyi válsághelyzetek és vis maior helyzetek kezelésérôl COM(2020) 613 végleges (2020. szeptember 23.)

17 European Commission: Final Report on Study on the Temporary Protection Directive, January 2016.
}

Európai Tükör 2021/2. 
csoportos státuszt. Napjainkban pedig iraki állampolgároknak Finnország, Románia és Svédország, szír állampolgároknak Németország nyújtott csoportos menedéket. ${ }^{18}$ Ennek ellenére az Irányelv átültetése lassú folyamatnak bizonyult. Mivel az Irányelv egy kötelezően átültetendő jogi aktusa volt az Európai Uniónak - Dánián kívül -, valamenynyi tagállam átültette az Irányelvet a tagállami jogrendszerbe, még akkor is, ha ez eltérő módon vagy mélységben történt. 2007-ig csak öt tagállam ültette át az Irányelvet teljes mértékig. ${ }^{19}$ Ennek fényében kifejezetten üdvözlendő, hogy a menedékjogról szóló 2007. évi LXXX. törvénnyel Magyarország az Irányelvet teljes mértékben átültette.

\section{Az átmeneti védelem szülkségessége}

2015-ben, a menekültügyi válság csúcsán 1,82 millió illegális határátlépést regisztráltak az EU külső határán, amely szám 2019-re 142 ezerre csökkent. A menedékjog iránti kérelmek száma 2015-ben 1,28 millió volt, 2019-ben pedig ennek csak a fele,698 ezer. Évente átlagosan mintegy 370 ezer nemzetközi védelem iránti kérelmet utasítanak el a tagállamokban, de a kérelmezőknek csak körülbelül egyharmadát küldik vissza hazájukba. Az EU által befogadott menekültek száma 2019 végén körülbelül 2,6 millió volt, ami az uniós népesség 0,6\%-ának felel meg. ${ }^{20}$ Ezenkívül az Európai Határ- és Partvédelmi Ügynökség (Frontex) adatai szerint 2017-ben összesen 204718 irreguláris migránst ${ }^{21}$ fogtak el. ${ }^{22}$ Bár ez csak töredéke a 2015-ben elfogott személyek számának, mégis azt lehet mondani, hogy a 2015 előtti évekhez képest fokozatosan nőtt a menekültügyi rendszerek leterheltsége a nagyszámú beáramlás eredményeként. Az Európai Unió területén ez a beáramlás nem csupán a belépési határpontoknál jelentkezik, így például Magyarország vagy Olaszország határain. A Frontex adatai szerint az irreguláris bevándorlók másodlagos mozgása érinti az Európai Unió külső határral nem rendelkező tagállamait is, így többek között Németországot, Hollandiát és a skandináv országokat is. ${ }^{23}$ Ezenkívül a Frontex adataiból - az irreguláris bevándorlók körülbelül 80\%-áról - az is megállapítható, hogy milyen földrajzilag jól meghatározható helyről (országból vagy országrészből) származnak. Ezek alapján az irreguláris bevándorlók számottevő része máig Szíriából, Afganisztánból, Nigériából, Irakból, Eritreából, Pakisztánból, Guineából, Elefántcsontpartról és Gambiából érkezik - többek között. ${ }^{24}$

Bizottsági Jelentés 4.

Bizottsági Jelentés, 12.

Európai Bizottság: A Bizottság közleménye az Európai Parlamentnek, a Tanácsnak, az Európai Gazdasági és Szociális Bizottságnak és a Régiók Bizottságának az új migrációs és menekültügyi paktumról COM(2020) 609 végleges (2020. szeptember 23.). 1-2.

${ }_{21}$ Az irreguláris bevándorló olyan harmadik országból származó személy, aki egy schengeni állam területén úgy tartózkodik, hogy nem felelt meg, vagy a továbbiakban nem felel meg a Schengeni Határvédelmi Rendeletnek (EU 2016/399) vagy nem teljesít más belépési, tartózkodási vagy letelepedési feltételt abban a tagállamban. Irreguláris migráns: https://ec.europa.eu/home-affairs/what-we-do/ networks/european_migration_network/glossary_search/irregular-migrant_en

Frontex: Risk Analysis for 2018. Warsaw, (2018. március). 16.

Frontex: Risk Analysis for 2017. Warsaw, (2017. február) 29. 4. ábra.

Frontex (2017): i. m. 18. 1. ábra.

Európai Tükör 2021/2. 
Egyes nemzetközi szervezetek, nevezetesen például az ENSZ Fejlesztési Programja (UNDP) - valamint a migrációkutatók - szerint a migráció kiváltó oka az emberi biztonság hiánya (human insecurity). A biztonságpolitika Koppenhágai Iskolája szerint az emberi bizonytalanság nem más, mint a gazdasági szegénység, a fegyveres konfliktus, a politikai instabilitás, az emberi jogok érvényesülésének veszélyeztetettsége és a természeti károk mint tényezők különböző kombinációja, illetve ezen tényezők összessége. ${ }^{25}$ Mindeközben egyre több tudományos kutatás jelenik meg arról, hogy melyek azok a térségek, amelyeket leginkább sújtják az éghajlatváltozás, illetve az ember által okozott környezetromlás következményei. A Világbank már 2005-ben megjelölte azokat a térségeket, amelyek leginkább kitettek a természeti csapásoknak. Az elemzés szerint a legnagyobb gazdasági veszteséggel járó természeti csapások főleg a Közel-Keleten és Dél-, Délkelet-Ázsiában várhatók, de erősen kitett az éghajlatváltozásnak már évtizedek óta az afrikai kontinens is. ${ }^{26} \mathrm{Az}$, hogy a természetben bekövetkező környezetromlás a helyi (fegyveres) konfliktusokhoz, illetve a jelenlegi migrációs trendekhez mindenképpen hozzájárul, mára vitathatatlan. ${ }^{27} \mathrm{Ha}$ pedig egy térképen összevetjük az irreguláris bevándorlók származási országait a Világbank által meghatározott, a természeti csapások szempontjából legsérülékenyebb térségekkel, majdnem teljes átfedést találunk.

Ennek fényében mindenképpen meg kell különböztetni az irreguláris migráción belül - Nagy Boldizsár értelmezése alapján - a „saját akaratából vagy gondatlanságból a szabályokat megszegő”, vagyis az „illegális migrációt”, és a „körülmények által vándorlásra kényszerített” személyeket, vagyis a „kényszervándorlást”. ${ }^{28}$ Utóbbi kategóriába tartozhatnak azok a személyek, akik környezeti okokból kényszerülnek elhagyni lakóhelyüket.

Ugyanakkor a természetes környezetben bekövetkezett romlás, az éghajlatváltozás közvetett, illetve közvetlen következményei, valamint a természeti csapások (a továbbiakban együttesen: a környezetromlás) miatt elvándorlók nemzetközi jogi definiálása még várat magára. ${ }^{29}$ Tekintettel arra, hogy a világban lezajló események nincsenek tekintettel a nemzeti, illetve nemzetközi jogalkotók lomhaságára, jelenleg ezeket a személyeket az ENSZ Menekültügyi Főbiztossága (UNHCR) és a Nemzetközi Migrációs Szervezet (IOM) munkája során a „lakóhelyüket környezeti okokból elhagyni kényszerült személyek" (environmentally displaced persons) fogalommal jelölik. Mindenesetre megjegyzendő, hogy ez a fogalom kizárólag a nemzetközi „soft-law” részét

25 Bonn International Center for Conversion: Brief 36. The Security-Migration Nexus. Challenges and Opportunities of African Migration to EU countries (2007. június). 75.

26 World Bank: Natural Disaster Hotspots: A Global Risk Analysis. The World Bank Hazard Management Unit, Washington D.C. (2005). 6. 1.2. ábra.

27 Bonn International Centre for Conflict Studies (2007): i. m. 26.

28 Nagy Boldizsár: A magyar menekültjog és menekültügy a rendszerváltozástól az Európai Unióba lépésig. Budapest, Gondolat, 2012. 61.

29 E tárgykörrel foglalkozó nemzetközi egyezmény nem létezik, és csak az ún. Berni Kezdeményezés záródokumentuma, az International Agenda for Migration and Management (2001) hozta a migrációt összefüggésbe a kényszermigrációval, pontosabban a kényszerủ lakhelyelhagyással: https://publications.iom.int/system/files/pdf/iamm.pdf; Lásd még: Horváth Valéria: Minek nevezzelek: klímamenekült vagy klímamigráns? Pécsi Határôr Tudományos Közlemények, 20. (2018), 245-252.

Európai Tükör 2021/2. 
képezi. ${ }^{30}$ Tehát az államok számára semmilyen nemzetközi jogi kötelezettséget nem teremt arra vonatkozóan, hogy a nemzeti bevándorlási politikájukat és az ennek keretet adó jogrendszerüket úgy alakítsák ki, hogy a környezeti katasztrófák elől menekülők részére az államterületükön - jogi - védelmet nyújtsanak.

Az Átmeneti védelemrôl szóló Irányelv az első uniós - akkor még közösségi - szabályozási eszköz volt a menekültügy terén. A jogalkotók pontosan egy olyan mechanizmus létrehozását vizionálták, amely egyrészt áthidalja a tagállamok menekültügyi rendszerei közötti hézagokat, másrészt konkrét - természetbeni és anyagi - segítséget nyújt a tagállami menekültügyi rendszerek tömeges leterheltsége esetén. Ennek megfelelően az irányelvnek két célkitűzése volt: 1. megállapítani az átmeneti/ideiglenes védelem minimumszintjét, és 2. elősegíteni a tagállamok közötti együttműködést és a menekültügyi rendszer terhének elosztását. ${ }^{31}$ Az Irányelvre különösen azért volt szükség, mivel a tagállami szuverenitás tiszteletben tartásával nem volt egységes és átfogó menekültügyi politika az EU-ban, hanem 27 különálló tagállami menekültügyi rendszer volt. Ezek ugyan találkoztak az EU Közös Menekültügyi Rendszerében, de még így is - az Unió jelenlegi külső határainak rendszere miatt - az egyik menekültügyi rendszer beomlása a többi tagállamra is kihat. ${ }^{32}$ Ennek megfelelően az átmeneti védelem az Irányelv szerint egy olyan „kivételes jellegű eljárás, amelynek célja a hazájukba visszatérni nem képes, lakóhelyüket elhagyni kényszerült, harmadik országból származó személyek tömeges beáramlása vagy várható tömeges beáramlása esetén azonnali és átmeneti védelem biztosítása az ilyen személyek részére, különösen akkor, ha annak kockázata is fennáll, hogy a menekültügyi rendszer nem lesz képes ezt a beáramlást feldolgozni anélkül, hogy ne érné hátrány annak hatékony működését az érintett, illetve a védelemért folyamodó más személyek érdekében". ${ }^{33}$

Tipikus esetben tehát az átmeneti védelem egy veszélyhelyzetet kíván kezelni, tudniillik tömeges bevándorlás esetére nyújt átmeneti megoldást. A menekült státuszhoz képest az átmeneti védelem csoportos és nem egyéni státuszt biztosít a kérelmezőnek. Ennek pontosan az az előnye, hogy egy előre nem látható és kiszámíthatatlan tömeges beáramlás esetén a menekültügyi rendszer lebénulhatna annál a rettentő praktikus oknál fogva, hogy az ügyintézők nem bírják az ügyterhet. Ennek elkerülése érdekében tudtak (volna) az Irányelvnek megfelelően a tagállamok csoportos bevándorlási státuszt nyújtani, miközben azonnali természetbeni segítséget is adtak volna az arra rászorulóknak. ${ }^{34}$

\footnotetext{
30 United Nations High Commissioner for Refugees: Protection Gaps. Framework for Analysis. Enhancing Protection of Refugees. UNHCR, 2008. 26.

Bizottsági Jelentés, 8.

Bizottsági Jelentés 17.

Irányelv 2. cikk a) bek.

Bizottsági Jelentés, 4.
} 


\section{Az átmeneti védelem alkalmazhatósága és kihasználatlansága}

A Genfi Egyezmények értelmében menekültként az a harmadik országból származó személy kaphat menedékjogot, aki faji, vallási okok, nemzeti hovatartozása, illetve meghatározott társadalmi csoporthoz való tartozása, avagy politikai meggyőződése miatti üldöztetéstől való megalapozott félelme miatt az állampolgársága szerinti országon kívül tartózkodik, és nem tudja, vagy az üldöztetéstől való félelmében nem kívánja annak az országnak a védelmét igénybe venni, vagy aki állampolgársággal nem rendelkezve és korábbi szokásos tartózkodási helyén kívül tartózkodva ilyen események következtében nem tud vagy az üldözéstől való félelmében nem kíván oda visszatérni. ${ }^{35} \mathrm{Az}$ Európai Unióban $^{36}$ a menekültstátuszon kívül kialakították az úgynevezett kiegészítő védelmet is, amely ugyan nem a Genfi Egyezmény szerinti menekült kategória, tehát e személyek köre valamilyen okból kifolyólag nem meríti ki a Genfi Egyezmény menekült definícióját, de hozzájuk hasonlóan ők is nemzetközi védelemre szorulnak, mert hazájuk védelmét nem élvezhetik valamilyen oknál fogva. A Genfi Egyezmény menekült fogalmának elemei ugyan taxatívnak tűnnek, mégsem mondható teljes körűnek, hiszen az egyezmény elfogadása idején nem tettek különbséget a „menekült” (refugee) és a „menekülő”, illetve „menedékkérő” (asylum seeker) között, ami jelenleg is nemzetközi jogi joghézagként jelentkezik. ${ }^{37}$ A tagállamok által - a Genfi Egyezmények keretei között - az uniós Irányelvek átültetésével kidolgozott menedékjogi eljárás célja annak megállapítása, hogy a kérelmező jogosult-e menekült- vagy oltalmazotti státuszra, illetve, hogy a származási országába visszaküldhető-e. ${ }^{38} \mathrm{Az}$ eljárási határidő pedig általában 60 nap, ez indokolt esetben 30 nappal meghosszabbítható, amely során van egy előzetes és egy részletes vizsgálati szakasz. ${ }^{39}$ Tekintettel arra, hogy a kérelmet a kérelmező személyesen köteles benyújtani, amelyet egyedi eljárásban egyedi döntéssel bírálnak el, a kérelmezők tömeges mértéke nemes egyszerűséggel megbéníthatja az eljáró hatóságokat. Az Irányelv alapján a tagállamokban azok a személyek kaphatnak menedékes státuszt és ezáltal részesülhetnek ideiglenes védelemben, akik az adott tagállam területére azért érkeztek tömeges mértékben, mert fegyveres konfliktus, polgárháború vagy etnikai összecsapás, illetve az emberi jogok általános, módszeres vagy durva megsértése - így különösen kínzás, kegyetlen, embertelen vagy megalázó bánásmód - miatt lakóhelyüket elhagyni kényszerültek..$^{40} \mathrm{~A}$ menedékes státusz csoportalapú, és e státusz megszerzésének feltétele a meghatározott csoporthoz való tartozás, az elismerés jogalapjához hozzátartozik, hogy az Európai Unió Tanácsa vagy az arra kijelölt nemzeti döntéshozatali szerv ideiglenes

35 Hegedűs Judit - Hautzinger Zoltán - Klenner Zoltán: A migráció elmélete. Budapest, Nemzeti Közszolgálati Egyetem Rendészettudományi Kar, 2014. 59.

36 A harmadik országbeli állampolgárok és hontalan személyek nemzetközi védelemre jogosultként való elismerésére, az egységes menekült- vagy kiegészítő védelmet biztosító jogállásra, valamint a nyújtott védelem tartalmára vonatkozó szabályokról szóló 2011/95/EU Irányelv alapján.

$37 \quad$ Nagy (2012): i. m. 59.

38 2007. évi LXXX. törvény a menedékjogról (Menekült tv.) 19. §.

39 Hegedûs-Hautzinger-Klenner (2014): i.m. 61.

40 Hegedűs-Hautzinger-Klenner (2014): i. m. 60.

Európai Tükör 2021/2. 
védelemre jogosultnak nyilvánítsa az adott személyek csoportját. ${ }^{41} \mathrm{~A}$ menedékes státusz, bár nem olyan kedvező, mint a menekülteké vagy az oltalmazottaké, mert például csak a külföldiekre vonatkozó általános szabályok szerint jogosultak a munkavégzésre, illetve az ideiglenes védelem időtartama mindössze egy év, ${ }^{42}$ mégis biztosít a rászorulóknak egy minimális szintű nemzetközi védelmet. Az ideiglenes védelem időtartama pedig korlátlan alkalommal meghosszabbítható. ${ }^{43}$

Az Irányelvet azonban sosem alkalmazták. Először - és utoljára - 2011-ben, tíz évvel az Irányelv hatálybalépését követően, Olaszország és Málta kérelmezte - külön-külön - az Európai Bizottságtól az arab tavasz miatt a Tunéziából érkező nagy- és növekedő számú menekülők fogadásakor a támogatást. Az Európai Bizottság azonban az előterjesztésüket nem támogatta, és nem is továbbította azt a döntési hatáskörrel rendelkező Tanácshoz. ${ }^{44}$ Ennek oka, hogy az Európai Bizottság jelentése szerint az Irányelv számos olyan elemet tartalmaz, amely paradox módon egyszerre az előnye és a hátránya is a szabályozásnak.

Az egyik legfontosabb ilyen elem a „tömeges beáramlás” fogalmi meghatározása. A „tömeges beáramlás” a lakóhelyüket elhagyni kényszerülő olyan személyeknek nagy számban az Unió területére történő érkezése, akik valamely előre megnevezett országból vagy földrajzi területről érkeztek, függetlenül attól, hogy spontán vagy támogatott módon - például evakuálás miatt - érkeztek-e az Unió területére. ${ }^{45}$ A Bizottsági jelentés szerint a jogalkotók szándékosan fogalmazták meg tágan ezt a jelenséget annak érdekében, hogy az alkalmazható legyen bármilyen jellegú beáramlásra, illetve migrációs nyomásra, és azt ne korlátozzák előre meghatározott számok, sem indikátorok. Az Irányelv lényege éppen az volt, hogy rugalmasan, ad hoc módon, az egyedi eseteknek megfelelően lehessen alkalmazni az átmeneti védelem szabályait. Így az Irányelv akár abban az esetben is alkalmazandó, ha a nemzetközi védelem iránti kérelmek hirtelen megnőnek - hirtelen beáramlás esetén -, de akár azok fokozatos növekedése vagy akár egy előre megtervezett evakuáció végrehajtása során, vagy akár akkor is, ha ezek kombinációja merül fel a valóságban. ${ }^{46}$ A tömeges beáramláskor ugyanakkor meg kell határozni azt is, hogy mi minősül „nagyszámúnak”. Ezt a fogalmi elemet azonban az Irányelv pontosabban nem határozza meg, így az, ahogy előrelátható volt, okozott is már a tagállamok körében vitát, a már említett Málta és Olaszország esetében. Mindenesetre megjegyzendő, hogy a lakóhelyüket elhagyni kényszerülők akkor jelennek meg jogi értelemben „nagyszámban”, ha már jelentős nyomást gyakorolnak arra a menekültügyi rendszerre, amelyben tömegesen nemzetközi védelemért folyamodnak, ezáltal veszélyeztetve a kérelmezők alapvető igényeinek kielégítését és jogaik érvényesítését.

$41 \quad$ Magyarországon például a Menekült tv. eredeti szövege szerint a magyar Országgyűlésnek volt hatásköre ez ügyben határozatot hozni. Azonban a magyar Országgyülés egy törvénymódosítással 2014-ben „átruházta” ezt a döntési jogkört a magyar kormány javára.

42 Hegedús-Hautzinger-Klenner (2014): i. m. 60.

43 Menekült tv. 23-24. §.

44 Bizottsági Jelentés, 13.

$45 \quad$ Irányelv 2. cikk d) bek.

$46 \quad$ Bizottsági Jelentés, 15. 
Már itt meg kell jegyezni, hogy a „nagyszám” alapját azonban egy nagyon speciális személyi kör képezi, amely lényegében megbénítja az Irányelv múködését. Erre a továbbiakban részletesebben is kitér a tanulmány.

Ahogy korábban már említettem, az Irányelv rugalmasságát a „lakóhelyüket elhagyni kényszerült személyek" definiálása töri meg végleg. Az Irányelv értelmében ők olyan harmadik ország állampolgárai vagy hontalan személyek, akiknek el kellett hagyniuk származási országukat, illetve régiójukat, vagy evakuálták őket, különösen nemzetközi szervezetek segítségével, és akik az adott országban fennálló helyzet miatt nem képesek biztonságos és tartós feltételek mellett visszatérni, vagy akik a genfi egyezmény $1 \mathrm{~A}$. cikkének, vagy más nemzetközi védelmet nyújtó nemzetközi vagy nemzeti jogszabály hatálya alá tartoznak”. Így különösen olyan személyek, akik: „i) fegyveres konfliktus vagy helyi erőszakos cselekmény helyszínéről menekültek el; vagy ii) akiknél emberi jogaik rendszeres vagy általános megsértésének komoly kockázata áll fenn, illetve ennek áldozatai". ${ }^{47}$ A rugalmatlanságot pedig a(z) - álláspontom szerint túlzott - fogalomszúkítés adja, mivel az Irányelv csak és kizárólag fegyveres konfliktus vagy az emberi jogok rendszeres és általános megsértése miatt menekülőkre vonatkozik. ${ }^{48} \mathrm{Ez}$ azonban rettentően gyakorlatiatlan, hiszen az Irányelv hatálybalépése óta is azt látjuk, hogy a tömeges mértékű beáramlás mindig vegyes migrációt jelent. A Bizottsági jelentésből azonban egyértelmű, hogy a kumulatív beáramlás, vagyis a különböző földrajzi területekről érkezők együttes átmeneti védelemben való részesítése fogalmilag kizárt. ${ }^{49}$

A tömeges beáramlás fogalmán belül az egyik leggyengébb fogalmi elem a „Közösség területére történő érkezés" meghatározása. Bár a jogalkotók itt is a rugalmasságra törekedtek az által például, hogy a lakóhelyüket elhagyni kényszerülő személyek érkezhetnek spontán vagy támogatott módon is, az Irányelv hallgat a beáramlás földrajzi hatóköréről. Ez egyrészt jelentheti azt is, hogy az Unióba való beáramlás nincs földrajzi területhez kötve, így az történhet akár egy bizonyos határátkelőhelynél, vagy egy tagállamot érintve, vagy akár több tagállamot érintően is. A tömeges beáramlás másik földrajzi fogalmi eleme, hogy a lakóhelyüket elhagyni kényszerülő személyek „valamely meghatározott országból vagy földrajzi területről” érkezzenek, vagyis a földrajzi származásnak jól körülhatárolhatónak és egységesnek kell lennie. A Bizottsági jelentésből egyértelmű, hogy a kumulatív beáramlás, vagyis a különböző földrajzi területekről érkezők együttes átmeneti védelemben való részesítése fogalmilag kizárt. ${ }^{50}$

Ezenkívül ezen a ponton azt is érdemes megjegyezni, hogy az Irányelv egy másik nagy mulasztást is elkövet. A hatályos szabályozás szerint a „Közösségbe való beáramlás” történhet spontán módon vagy előre megszervezetten. Az Irányelv ezek szerint egy olyan lehetőséget is vizionált, hogy a tagállamok, akár külön, akár uniós szinten megterveznek és megszerveznek egy evakuációs stratégiát, és a lakóhelyüket elhagyni

\footnotetext{
$47 \quad$ Irányelv 2. cikk c) bek.

48 Kérdés azonban, hogy mennyire tekinthető maga a környezetromlás az emberi jogok megsértésének vagyis, hogy egy természeti csapás okán elvesztett otthon sérti-e az áldozatnak - az 1966-os A Gazdasági, szociális és kulturális jogok nemzetközi egyezségokmányának 11. cikkjében meghatározott - megfelelő lakhatásához való jogát. Md Shamsuddoha - Rezaul Karim Chowdhury: Climate Change Induced Forced Migrants: in need of dignified recognition under a new Protocol. 2009. 7.

49 Bizottsági Jelentés, 18.

50 Bizottsági Jelentés, 18.
} 
kényszerülők nem spontán módon, hanem szervezetten áramolnak be az Unió területére. ${ }^{51}$ Nem szabad elfelejteni, hogy a származási országok és a migráció alapjául szolgáló okok a döntéshozók számára elérhetők, így a Földközi-tenger emberi katasztrófái akár elkerülhetők is lehetnének az által, hogy tengeri mentőakciók helyett megelőző evakuációs stratégiákat léptetnek életbe, amelyekkel nemcsak a biztonságos, de a jogszerű, reguláris migrációt segítenék elő. ${ }^{52}$

$\mathrm{Az}$ eredeti elgondolás szerint a Bizottság tehát saját hatáskörben mérte fel, hogy az adott tagállam valóban meg tud-e küzdeni az ügyteherrel, illetve, hogy vajon elhúzódik-e az alapkonfliktus, és végül, hogy milyen mértékben és milyen segítségre szorul az adott tagállam. A Bizottságnak tehát azt kellett volna vizsgálnia, hogy milyen következményei és hatásai vannak az akár fokozatos, akár a hirtelen beáramlásnak, vagy akár az evakuációnak a tagállam menekültügyi rendszerére, az uniós menekültügyi rendszerre, valamint a tagállam, illetve az Unió azon nemzetközi kötelezettségeinek teljesítésére, hogy megfelelő eljárásban részesítsék a nemzetközi védelemre szorulókat. ${ }^{53}$ Ugyanakkor a gyakorlat azt mutatta, hogy a Bizottság a diszkrecionális jogát és az Irányelv rugalmasságát nem kezelte nagyvonalúan. Bár Ciprus számos alkalommal bocsátott a Bizottság rendelkezésére számszerű adatokat arra vonatkozóan, hogy a menekültstátuszért, illetve nemzetközi védelemért folyamodó személyek mekkora pénzbeli, természetbeni és emberi erőforrásbeli terhet jelentenek a ciprusi menekültügyi rendszerre, a Bizottság álláspontja szerint az Irányelv az ilyen vegyes migrációs áramlásokra nem alkalmazható. ${ }^{54}$ Málta esetében a Bizottság nemes egyszerűséggel nem találta elég „nagyszámúnak” a szigetre érkezőket. ${ }^{55}$ Olaszország esetében pedig a Bizottság úgy döntött, hogy Olaszország menekültügyi rendszere elbírja a terhet, és mivel a szírai menedékkérők 98\%-ának a menekült kérelmét jóváhagyják, így jogaik nem sérülnek. ${ }^{56}$ Mindkét ország esetében a Bizottság úgy vélte, hogy máshogy is lehet segítséget nyújtani a tagállamoknak.

\section{Az Új Migrációs és Menekültügyi Csomag}

Az uniós segítség 2015-ben az úgynevezett European Agenda for Migration formájában érkezett, amely azonnali, célzott segítséget nyújtott (volna) a menekültválsággal küzdő tagállamoknak. Az azonnali segítségnyújtás keretében - többek között - a tengeri

$51 \quad$ Bizottsági Jelentés, 17.

52 1999-ben a UNHCR evakuációs programján keresztül a jugoszláv háború következtében majdnem 92 ezer menekülőt evakuáltak 29 különböző országba. Astri Suhrke et al.: The Kosovo refugee crisis. UNHCR, 2000. 94; 2005-ben a Pápua Új-Guinea-i Carteret-szigetek eltűntek és az egyéni menekülés mellett 1000 lakost sikerült áttelepíteni Bougainvillebe, egy 62 mérfölddel messzebb fekvő szigetre. Mariya Gromilova: Revisiting Planned Relocation as a Climate Change Adaptation Strategy: The Added Value of a Human Rights-Based Approach. Utrech Law Review, 10. (2014), 1. 76-95.

Bizottsági Jelentés, 16.

Bizottsági Jelentés, 18.

Bizottsági Jelentés, 13.

Bizottsági Jelentés, 19.

Európai Tükör 2021/2. 
mentések esetében a Frontex-, Triton- és a Poseidon ${ }^{57}$-műveletek költségvetésének megtriplázására, az embercsempész-hálózatok beazonosítása és felszámolása érdekében a Közös Biztonság- és Védelempolitika célzott alkalmazására, a tömeges beáramlásra való válaszként a tagállamok közötti áthelyezések (relocation) elrendelésére, valamint a UNHCR-ral való együttmüködés keretében a lakóhelyüket elhagyni kényszerülők, az őket megillető nemzetközi védelem érdekében történő áttelepítésére került sor. ${ }^{58}$ Míg a tengeri mentési akciók sikeresnek mondhatók, addig a menekülők tagállamok közötti áthelyezése akkora kudarcba fulladt, hogy a 2015-ös menekültválság az Európai Unió válságába torkollott.

A 2015-ös európai menekültválság - aztán a 2020-as Covid-járvány - okán a tagállamok túlontúl könnyedén lemondtak az Unió egyik alapszabadságáról, a személyek szabad áramlásáról azzal, hogy Ausztria, Dánia, Franciaország, Németország, Norvégia és Svédország felfüggesztette a Dublin-, illetve a Schengen-rendszert. ${ }^{59}$ Néhány tagállam még az úgynevezett Global Compact for Migration ENSZ-kezdeményezésből is visszalépett. ${ }^{60}$ A 2015-ös menekültválság után öt hosszú évnek kellett tehát eltelnie, hogy az Unió átfogóan és stratégiailag tudjon rá reagálni.

2020. szeptember 23-án jelentette be az Európai Bizottság az Új Migrációs és Menekültügyi Csomagot, amelynek célja, hogy átfogó módon javítson és gyorsítson a tagállami menekültügyi és bevándorlási eljárásokon (első pillér), egyensúlyt alakítson ki a tagállamok közötti felelősség- és szolidaritásvállalás eloszlásában (második pillér), és mindent egybevetve helyreállítsa a tagállamoknak az Unióba vetett bizalmát a tekintetben, hogy az Unió képes kezelni az uniós tagállamokat - külön-külön vagy együttesen - érintő migrációs nyomást. A von der Leyen Bizottság az ad hoc, hot spot fókuszú megoldások helyett az általános jogbiztonságot kívánja helyreállítani, vagyis kiszámítható és megbízható menekültügyi rendszereket alakítana ki. ${ }^{61} \mathrm{~A}$ migrációs nyomás, az egységes válságkezelés fontosságának felismerését és az erőteljesebb uniós fellépést tükrözi, hogy az új Migrációs és Menekültügyi Csomag új jogszabályai túlnyomórészt közvetlenül alkalmazandó rendeletek - a módosítandó jogszabályokkal (irányelvekkel) szemben.

57 A Frontex tagállamai a Triton-művelet keretében Olaszország, Szicília és Málta partjainál, a Poseidon-művelet kereteiben pedig Görögország és Törökország partjainál segítették a helyi hatóságokat. Forrás: European Commission Factsheet on EU Operations in the Mediterranean Sea (2016).

58 European Commission: Communication from the Commission to the European Parliament, the Council, the European Economic and Social Committee and the Committee of the Regions: A European Agenda on Migration $\operatorname{COM}(2015) 240$ final (2015. május 13.). 3-4.

59 European Parliament: Tanja Fajon: „If we lose Schengen, we will lose the European project” (2018. november 23.).

60 Öt ország ellenszavazata között volt az Unióból Magyarország, Csehország, és Lengyelország, és tartózkodott Ausztria, Bulgária, Olaszország, Lettország és Románia. Georgi Gotev: Nine EU members stay away from UN migration pact. Euractive, 2018. december 20; International Organization for Migration (2019): i. m 94.

61 European Commission: A fresh start on migration: Building confidence and striking a new balance between responsibility and solidarity (2020. szeptember 23.).

Európai Tükör 2021/2. 


\subsection{A migrációs és menekültügyi válság kezelésérôl szóló rendelet}

Az új Migrációs és Menekültügyi Csomag részeként a Bizottság kidolgozta az új úgynevezett Migrációs Felkészültségi és Válságkezelési Tervet, amely elősegíti, hogy az Unió reaktív, ad hoc válságkezelése elmozduljon az előrejelzés és a felkészülés felé. A Felkészültségi és Válságkezelési Terv összefog minden rendelkezésre álló válságkezelési eszközt, és meghatározza azokat a kulcsfontosságú intézményi, operatív és pénzügyi intézkedéseket, protokollokat, amelyeknek mind uniós, mind tagállami szinten meg kell valósulniuk a válságra való felkészültség biztosítása során. A különböző válságkezelési eszközök közül egy új jogi eszköz fog rendelkezni a válság idején szükséges ideiglenes és rendkívüli intézkedésekről. Ez a már korábban említett Válságkezelési Rendelet, amelynek elfogadásával az Átmeneti Védelemről szóló Irányelv hatályát veszti. ${ }^{62}$

A Rendelet szerint a válsághelyzet egy olyan rendkívüli helyzet, amelyben harmadik ország állampolgárainak vagy hontalan személyek tömeges beáramlására kerül sor egy tagállamba - illegális határátlépéssel vagy partraszállással -, és amelynek mértéke a tagállam népességéhez és GDP-jéhez mérve (50-50\%), és annak természeténél fogva működésképtelenné teszi a tagállam menekültügyi rendszerét, és komoly következményei lehetnek a Közös Európai Menekültügyi Rendszerre, illetve az új Menekültügyi és Migrációkezelési keretrendszerre nézve. Szintén rendkívüli helyzetnek minősül, ha ezeknek a körülményeknek „csak” a közvetlen veszélye áll fenn, vagyis már az előrelátható válságokat is megkísérelheti kezelni a Bizottság. ${ }^{63}$ Már ezen a ponton érdemes megjegyezni, hogy az Átmeneti Védelemről szóló Irányelvvel szemben elsőre praktikusabbnak tűnhet a Válságkezelési Rendelet, mivel az Irányelv egyik hiányossága a „tömeges beáramlás” mértékének meghatározása volt. Bár a Rendeletben megjelenik a népesség- és GDP-arányos leterheltség, ezek még mindig olyan irányszámok, amelyek továbbra is teret engednek a tagállamok és a Bizottság közötti félreértéseknek.

A Válságkezelési Rendelet alappillérei a válság során fellépő eljárási nehézségekre vonatkozó segítség és tulajdonképpen a tagállamokkal szembeni türelem - vagyis a menekültügyi eljárásoktól való derogáció lehetősége -, a tagállamok közötti kötelező, de rugalmas szolidaritásvállalás, és az azonnali védelem biztosítása a menedékkérők számára.

Az olyan volumenú válsághelyzetekben, amelyek a tagállamok menekültügyi és migrációs rendszereinek túlterhelésével fenyegetnek, a Válságkezelési Rendelet alapján a Bizottság egy válságkezelési tervben megállapíthatja a tagállamok által tapasztalt gyakorlati nehézségeket, és lehetővé tenné - korlátozott mértékben - a rendes eljárásoktól és határidőktől való ideiglenes eltérést, miközben változatlanul biztosítottak lennének az érintettek alapvető jogai és a visszaküldés tilalma. ${ }^{64}$ Tekintve, hogy a Rendelet tulajdonképpen rendkívüli jogalkalmazást jelent, az a rendes menekültügyi eljárásrendektől enged eltérést rendkívüli helyzetekben. ${ }^{65}$ Ennek megfelelően az érintett tagállamoknak

\footnotetext{
62 Megjegyzendő viszont, hogy a válságkezelési rendelet nem érinti a Tanácsnak azon szolidaritásvállalási jogát, hogy az EUMSZ 78. cikk 3. bekezdése értelmében ideiglenes intézkedéseket rendeljen el a Bizottság javaslatára, ha egy tagállam veszélyhelyzetbe kerül.

Válságkezelési Rendelet 1. cikk 2. bek.

$\operatorname{COM}(2020) 609.12$

Válságkezelési Rendelet 1. cikk 1. bek.
}

Európai Tükör 2021/2. 
indokolással ellátott kérelmet kell benyújtaniuk a Bizottsághoz, ha úgy ítélik meg, hogy válsághelyzetben vannak, és szükségesnek tartják akár a válságkezelési menekültügyi eljárás, akár a válságkezelési kiutasítási eljárás alkalmazását, vagy eltéréseket kell alkalmazniuk a nemzetközi védelem iránti kérelmek nyilvántartásba vételére vonatkozó rendelkezések tekintetében. Az eltérések külön-külön vagy együttesen is kérelmezhetők, azonban az egyes cikkek alkalmazására meghatározott feltételeknek külön-külön meg kell felelni. Egy vagy több érintett tagállam kérelmére a Bizottság végrehajtási határozat útján - amely egy vagy több tagállamra vonatkozhat - engedélyezi az eltérési szabályok alkalmazását az ugyanezen határozatban meghatározandó időtartamra. Tekintettel arra, hogy esetleg azonnali intézkedésekre van szükség, a tagállamok egyoldalú módon legfeljebb 15 napos időszakra elkezdhetik alkalmazni a nyilvántartásba vétel határidejének meghosszabbítására vonatkozó rendelkezést. Ennek elteltével pedig a Bizottság vagy engedélyezi a rendelkezés további alkalmazását, vagy ezzel ellentétes döntést hoz.

$\mathrm{Az}$ Átmeneti Védelemről szóló Irányelvhez képest a tagállam kérelmére nem a Bizottság tesz javaslatot a Tanácsnak, hanem a Bizottság saját hatáskörben dönt. Ráadásul a Bizottság tagállami kérelem előterjesztése nélkül is dönthet úgy saját hatáskörben - quasi ex officio -, hogy életbe lépteti a Rendeletet. A Bizottság döntése kiterjedne a válsághelyzet megállapítására, a nemzetközi védelem feltételei megléte vizsgálatának felfüggesztésére, a származási ország (vagy országrész) meghatározására, valamint a rendkívüli intézkedések alkalmazása tartamának meghatározására. ${ }^{66}$ Bár a döntéshozatali láncolatból kikerült a Tanács, a Bizottság ritkán rendelkezik önállóan annyi közvetlen információval, hogy gyorsan fel tudja mérni, hogy egy tagállam kitett-e a válságnak.

Álláspontom szerint a rendkívüli intézkedések körében kiemelt hangsúlyt kaptak azok, amelyek a tagállamokkal szembeni elvárásokat puhítják egy tömeges beáramlás esetén. Bár a jelen tanulmánynak nem tárgya és célja az EU belpolitikai válságát taglalni, mindenképpen meg kell említeni, hogy a Bizottság a rendkívüli intézkedésekkel az EU-szkeptikus, szolidaritásellenes tagállamok kegyeit keresi.

Azzal párhuzamosan, hogy a Válságkezelési Rendelet számos kedvezményt biztosít a tagállamok számára válság idején az új Menekültügyi és Migrációs Csomag többi elemének alkalmazásától, a Rendelettel az Európai Unió „kötelező, de rugalmas” szolidaritásvállalást ír elő a tagállamok számára. Ez a kötelező, de rugalmas szolidaritásvállalás azt jelenti, hogy amennyiben a Bizottság dönt a válsághelyzet kihirdetéséről, a tagállamoknak kötelezően választania kell a segítségnyújtás meghatározott eszközei közül. Vagyis amennyiben a Bizottság dönt a válsághelyzetről, egy válságkezelési tervet fogad el, és összehív egy szolidaritási fórumot. Ezt követően a tagállamoknak pedig válsághelyzeti szolidaritási reagálási tervet kell benyújtaniuk egy héten belül. Ezután a Bizottság további egy héten belül elfogadja a végrehajtási jogi aktust, amely minden egyes tagállamra vonatkozóan meghatározza a szolidaritási intézkedéseket. ${ }^{67}$

A szolidaritásvállalás történhet egy másik tagállamban már státusszal rendelkező, a Közös Menekültügyi Keretrendszer által áthelyezett személyek befogadásával, vagy egy tagállam által visszaküldésre kijelölt személy visszaküldésének támogatásával.

\footnotetext{
66 Válságkezelési rendelet 10. cikk.

67 A Válságkezelési Rendelet indokolása.
} 
Megjegyzendő, hogy az áthelyezés a határon folytatott eljárás keretében nemzetközi védelmet kérelmező személyekre, az irreguláris migránsokra és a Rendelet szerint azonnali védelemben részesített személyekre is alkalmazandó. Ezenkívül amennyiben a visszaküldés nem zárul le sikeresen négy hónapon belül a visszaküldést elrendelő tagállamban, a visszaküldési szponzorálás hatálya alá tartozó, jogellenesen ott tartózkodó harmadik országbeli állampolgárokat vagy hontalan személyeket a válsághelyzetben lévő tagállamból a szponzoráló tagállamba szállítják át. Egy másik lehetőség a menedékkérők átvételét megtagadó tagállamok számára, ha szakértőkkel vagy gyakorlati segítséggel támogatják a frontvonalban lévő országokat, például a befogadóközpontok fenntartásának és irányításának anyagi segítésével. Azokat az államokat pedig, amelyek elutasítják bármelyik lehetőséget, a Rendelet szankcionálni rendeli, de a szankciót magát nem határozza meg. ${ }^{68} \mathrm{Ha}$ egy tagállam azonban maga is válságban van és szolidaritási támogatási intézkedések kedvezményezettje, a tagállam értelemszerúen mentesül a szolidaritásvállalási kötelezettség alól.

Ezenkívül a Válságkezelési Rendelet a Kvalifikációs Irányelvben meghatározott kiegészítő védelemmel egyenértékű „azonnali védelmet” vezet be. Az azonnali védelem alkalmazásának szükségességét és az érintett személyek pontos körét a Bizottság határozza meg a fent említett végrehajtási jogi aktusban. Ahogy már említettem, a tagállamok a végrehajtási jogi aktusban meghatározott alkalmazási időszak alatt felfüggeszthetik a nemzetközi védelem iránti kérelmek vizsgálatát, és az adott kritériumoknak megfelelő személyeknek azonnali védelmet biztosíthatnak. A felfüggesztési időszak legfeljebb egy évre hosszabbítható meg, és ezt követően újra meg kell kezdeni a menedékjog iránti kérelmek vizsgálatát. Ha ekkor a menedékjogi kérelemre vonatkozóan a tagállam megállapítja, hogy megalapozatlan volt, a menedékkérőt visszafordíthatja. Mindez biztosítja az érintett személyek számára a szükséges védelmet, ugyanakkor enyhíti a tagállamra nehezedő nyomást. Ez pedig különösen azért fontos, mert egy természeti katasztrófa esetén a katasztrófa áldozatai időt nyerhetnek, amíg a helyreállítási munkálatok folynak. Ugyanakkor a lassú lefolyású környezetromlás áldozatainak nem ideiglenes védelemre van szükségük, hanem egy végleges megoldásra, egy letelepedési engedélyre.

Ezenkívül az Átmeneti Védelemről szóló Irányelvhez hasonlóan azonnali védelemben kizárólag azon személyek előre meghatározott csoportja részesíthető - a Bizottság döntése alapján -, akik „a származási országukban dúló fegyveres konfliktus miatt a megkülönböztetés nélküli erőszak kivételesen magas kockázatának vannak kitéve hazájukban” ${ }^{69} \mathrm{Ez}$ azt jelenti, hogy nemcsak a lassú lefolyású, fokozatosan jelentkező környezetromlás áldozatai számára nem nyújt védelmet az Unió a Válságkezelési Rendelettel, de a hirtelen bekövetkező természeti katasztrófák elől menekülők részére sem. Ebből a szempontból pedig a vegyes migráció kezelése alulmúlja a várakozásokat.

\footnotetext{
$68 \quad$ A Schuman Intézet szerint ez az eljárásrend hosszadalmas lesz, és egyelőre még nincs egy közös uniós lista a biztonságos harmadik országokról, azokat a tagállamok egyelőre egyedül állapítják meg. Fondation Robert Schuman: Understanding the new pact on migration and asylum (2020. november 16.). 


\section{Következtetések}

Ahogy a tanulmány elején említettem, a környezeti okokból lakóhelyüket elhagyni kényszerülő személyek legalább annyian vannak már most, mint ahányan fegyveres konfliktus elől menekülnek. Ugyanakkor azokat, akik „elmenekülnek” otthonukból és hazájukból, az elvándorlást „választják” túlélési stratégiaként, a politikai közélet „gazdasági migránsnak” nevezi. Ez a stratégia azonban nem szabad akaratból történik, így az érintettek alapvető emberi jogai súlyosan sérülnek. Ebből kifolyólag a lakóhelyüket környezeti okok miatt elhagyni kényszerülőkkel foglalkozni kell a nemzetközi jog, a nemzeti és az uniós jogrendszer(ek) kereteiben is.

A tömegesen érkezők kezelésének szabályozására vannak már többé-kevésbé megfelelő jogi eszközök. Az uniós Átmeneti Védelemről szóló Irányelv pontosan ilyen lett volna, és a Válságkezelési Rendelet ilyen lehet. Az Irányelv legnagyobb önellentmondása a Bizottság szerint az volt, hogy bár tehermentesítésre törekszik, a tagállamokra a „gazdasági bevándorlók" által rótt terhet nem tudja semlegesíteni. ${ }^{70}$ A Válságkezelési Rendelet önellentmondása pedig az, hogy bár az előrejelzésekre támaszkodik és felkészültségre törekszik, mégsem foglalkozik a 21. század egyik legégetőbb problémájával, a környezeti okokból menekülőkkel. A Rendeletnek valóban előnye, hogy egyértelműsíti a rendkívüli helyzethez kapcsolódó rendkívüli eljárásrendet, amely az Irányelvből hiányzott, mivel ott inkább ideiglenességről („átmeneti védelem”) volt szó. Egy további fontos hasonlóság az Irányelv és a Rendelet között, hogy mindkét jogszabály fegyveres konfliktushoz köti a rendkívüli helyzetet. Ez viszont sajnos nem tükrözi azokat a nemzetközi trendeket, amelyeket a tanulmány elején is írtam, hogy a környezetkárosodás, illetve az éghajlatváltozás hatásai elől - a jövőben előreláthatóan tömegesen - egyre többen menekülnek. Így a Rendelet sem a menekülők, sem a tagállamok helyzetén nem segít. Ez pedig nemcsak morálisan vet fel aggályokat, hanem megkérdőjelezheti az EU képességét arra, hogy a nemzetközi trendekkel lépést tartson, és valóban felkészült legyen a válságkezelésre.

Ezek alapján tisztán jogi és az emberi méltóság szempontjából a Rendeletet szükséges lenne kiterjeszteni a vegyes migráción túl a lakóhelyüket környezeti okokból elhagyni kényszerülőkre. Ezenkívül pedig kifejezetten azokra a földrajzilag jól körülhatárolható országokra és térségekre kellene kiterjeszteni a Rendelet alkalmazását, amelyek kitettsége a környezetkárosodásnak, illetve a természeti csapásoknak jelentős. Az uniós fellépésre pedig azért lenne szükség, mert az Európai Migrációs Hálózat szerint csak két tagállamban, Olaszországban és Svédországban van az éghajlatváltozásból és természeti katasztrófákból fakadó tagállami védelmi státusz. A többi tagállamban maximum ad hoc alapon biztosított humanitárius vízumot és humanitárius célú tartózkodási engedélyt bocsáthatnak ki a tagállamok. ${ }^{71}$

Bizottsági Jelentés, 18.

https://emn.ie/wp-content/uploads/2020/05/emn_inform_nat_prot_statuses_final.pdf

Európai Tükör 2021/2. 


\section{Felhasznált irodalom}

Africa Center for Strategic Studies: African Migration Trends to Watch in 2021 (2020). Online: https://reliefweb.int/sites/reliefweb.int/files/resources/africacenter.org-African\%20 Migration\%20Trends\%20to\%20Watch\%20in\%202021.pdf

African Union: Report on Labour Migration Statistics in Africa (2017). Online: https:// au.int/sites/default/files/documents/39323-doc-web254_184-10_english_2nd_ edition_of_the_africa_labor_migration_statistics.pdf

Asian Development Bank: Addressing Climate Change and Migration in Asia and the Pacific (2012). Online: www.adb.org/sites/default/files/publication/29662/addressing-climate-change-migration.pdf

Bonn International Center for Conversion: Brief 36. The Security-Migration Nexus. Challenges and Opportunities of African Migration to EU countries (2007. június). Online: www.bicc.de/uploads/tx_bicctools/brief36.pdf

European Commission: Communication from the Commission to the European Parliament, the Council, the European Economic and Social Committee and the Committee of the Regions: A European Agenda on Migration COM(2015) 240 final (2015. május 13.).

European Commission: A fresh start on migration: Building confidence and striking a new balance between responsibility and solidarity (2020. szeptember 23.). Online: https:// ec.europa.eu/commission/presscorner/detail/en/ip_20_1706

European Commission: Final Report on Study on the Temporary Protection Directive, January 2016. (2021. november 22.) Online: https://ec.europa.eu/home-affairs/ system/files/2020-09/final_report_evaluation_tpd_en.pdf

European Parliament: Tanja Fajon: „If we lose Schengen, we will lose the European project” (2018. november 23.). Online: www.europarl.europa.eu/news/en/headlines/priorities/eu-borders/20181116STO19210/schengen-suspension-how-long-shouldinternal-border-checks-last

Fondation Robert Schuman: Understanding the new pact on migration and asylum (2020. november 16.). Online: www.robert-schuman.eu/en/european-issues/0577understanding-the-new-pact-on-migration-and-asylum

Food and Agriculture Organization: The Linkages between Migration, Agriculture, Food Security, and Rural Development (2018). Online: www.fao.org/3/CA0922EN/ ca0922en.pdf

Frontex: Risk Analysis for 2017. Warsaw, (2017. február). Online: https://doi.org/10. 2819/250349

Frontex: Risk Analysis for 2018. Warsaw, (2018. március). Online: https://doi.org/10. 2819/460626

Gotev, Georgi: Nine EU members stay away from UN migration pact. Euractive, 2018. december 20. www.euractiv.com/section/global-europe/news/nine-eu-members-stay-away-from-un-migration-pact/

Gromilova, Mariya: Revisiting Planned Relocation as a Climate Change Adaptation Strategy: The Added Value of a Human Rights-Based Approach. Utrech Law Review, 10. (2014), 1. 76-95. Online: https://doi.org/10.18352/ulr.258 
Hegedűs Judit - Hautzinger Zoltán - Klenner Zoltán: A migráció elmélete. Budapest, Nemzeti Közszolgálati Egyetem Rendészettudományi Kar, 2014. Online: http://m. ludita.uni-nke.hu/repozitorium/handle/11410/10038

Horváth Valéria: Minek nevezzelek: klímamenekült vagy klímamigráns? Pécsi Határör Tudományos Közlemények, 20. (2018), 245-252. Online: www.pecshor.hu/periodika/ XX/horvath.pdf

Internal Displacement Monitoring Center: Global Report on Internal Displacement (2018).

Online: www.internal-displacement.org/global-report/grid2018/

Internal Displacement Monitoring Center: Global Report on Internal Displacement (2019). Online: www.internal-displacement.org/global-report/grid2019/

Internal Displacement Monitoring Center: No matter of choice: displacement in a changing climate (2018). Online: www.internal-displacement.org/sites/default/files/publications/documents/20181213-slow-onset-intro.pdf

International Organization for Migration: Migration, Environment and Climate Change: Assessing the Evidence. Geneva, Switzerland, 2009. Online: https://publications.iom. int/system/files/pdf/migration_and_environment.pdf

International Organisation for Migration: World Migration Report 2020. Geneva, Switzerland, 2019. Online: https://publications.iom.int/system/files/pdf/wmr_2020.pdf

Mohamoud, Awil - Alpha Kaloga - Sönke Kreft: Climate change, development, and migration: an African Diaspora Perspective. German Watch - African Diaspora Policy Center, 2014. Online: https://germanwatch.org/sites/default/files/publication/9112. pdf

Nagy Boldizsár: A magyar menekültjog és menekültügy a rendszerváltozástól az Európai Unióba lépésig. Budapest, Gondolat, 2012.

Shamsuddoha, Md - Rezaul Karim Chowdhury: Climate Change Induced Forced Migrants: in need of dignified recognition under a new Protocol. 2009. Online: www.mediaterre. org/docactu,Q0RJLUwtMy9kb2NzL2NsaW1hdGUtbWlncmFudC1wcmludGVkLXBvc210aW9uLWR1Yy0wOQ==,1.pdf

Suhrke, Astri - Michael Barutciski - Peta Sandison - Rick Garlock: The Kosovo refugee crisis. UNHCR, 2000. Online: www.alnap.org/system/files/content/resource/files/ main/erd-2848-full.pdf

United Nations High Commissioner for Refugees: Protection Gaps. Framework for Analysis. Enhancing Protection of Refugees. UNHCR, 2008. Online: www.unhcr.org/protect/ PROTECTION/41fe3ab92.pdf

World Bank: Natural Disaster Hotspots: A Global Risk Analysis. The World Bank Hazard Management Unit, Washington, D.C. (2005).

Európai Tükör 2021/2. 


\section{Jogi források}

2007. évi LXXX. törvény a menedékjogról

A Bizottság közleménye az Európai Parlamentnek, a Tanácsnak, az Európai Gazdasági és Szociális Bizottságnak és a Régiók Bizottságának az új migrációs és menekültügyi paktumról COM(2020) 609 végleges (2020. szeptember 23.). Online: https:// eur-lex.europa.eu/resource.html?Uri=cellar:85ff8b4f-ff13-11ea-b44f-01aa75ed71a1.0006.02/DOC_18format=PDF

Európai Bizottság: Javaslat Az Európai Parlament és a Tanács Rendelete a migrációs és menekültügyi válsághelyzetek és vis maior helyzetek kezeléséröl COM(2020) 613 végleges (2020. szeptember 23.). Online: https://eur-lex.europa.eu/legal-content/HU/ TXT/?uri=CELEX:52020PC0613\&qid=1604472929883

Az Európai Parlament és a Tanács 2011/95/EU Irányelve (2011. december 13.) a harmadik országbeli állampolgárok és hontalan személyek nemzetközi védelemre jogosultként való elismerésére, az egységes menekült- vagy kiegészítő védelmet biztosító jogállásra, valamint a nyújtott védelem tartalmára vonatkozó szabályokról

A Tanács 2001/55/EK Irányelve (2001. július 20.) a lakóhelyüket elhagyni kényszerült személyek tömeges beáramlása esetén nyújtandó átmeneti védelem minimumkövetelményeiről, valamint a tagállamok e személyek befogadása és a befogadás következményeinek viselése tekintetében tett erőfeszítései közötti egyensúly előmozdítására irányuló intézkedésről 